\title{
Structural, morphological, and optical properties of Bi2O3 thin films grown by reactive sputtering
}

Petru Lunca Popa, Steffen Sønderby, Sit Kerdsongpanya, Jun Lu, Hans Arwin and Per Eklund

\author{
Journal Article
}

\section{Tweet}

N.B.: When citing this work, cite the original article.

Original Publication:

Petru Lunca Popa, Steffen Sønderby, Sit Kerdsongpanya, Jun Lu, Hans Arwin and Per Eklund, Structural, morphological, and optical properties of Bi2O3 thin films grown by reactive sputtering, Thin Solid Films, 2017. 624, pp.41-48.

http://dx.doi.org/10.1016/j.tsf.2017.01.013

Copyright: Elsevier

http://www.elsevier.com/

Postprint available at: Linköping University Electronic Press

http://urn.kb.se/resolve?urn=urn:nbn:se:liu:diva-136305

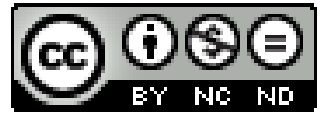




\section{Accepted Manuscript}

Structural, morphological, and optical properties of $\mathrm{Bi} 2 \mathrm{O} 3$ thin films grown by reactive sputtering

P. Lunca Popa, S. Sønderby, S. Kerdsongpanya, J. Lu, H. Arwin, P. Eklund

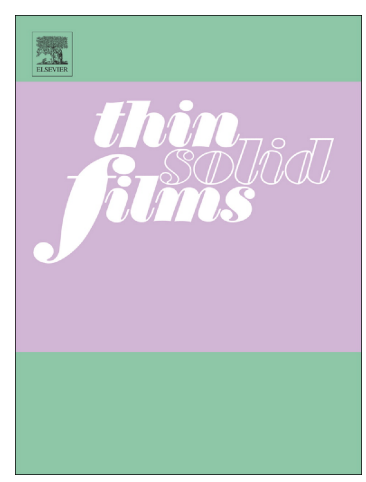

PII: S0040-6090(17)30013-5

DOI: doi: 10.1016/j.tsf.2017.01.013

Reference: TSF 35725

To appear in: Thin Solid Films

Received date: $\quad 22$ July 2016

Revised date: $\quad 22$ December 2016

Accepted date: $\quad 9$ January 2017

Please cite this article as: P. Lunca Popa, S. Sønderby, S. Kerdsongpanya, J. Lu, H. Arwin, P. Eklund, Structural, morphological, and optical properties of $\mathrm{Bi} 2 \mathrm{O} 3$ thin films grown by reactive sputtering. The address for the corresponding author was captured as affiliation for all authors. Please check if appropriate. $\operatorname{Tsf}(2017)$, doi: 10.1016/j.tsf.2017.01.013

This is a PDF file of an unedited manuscript that has been accepted for publication. As a service to our customers we are providing this early version of the manuscript. The manuscript will undergo copyediting, typesetting, and review of the resulting proof before it is published in its final form. Please note that during the production process errors may be discovered which could affect the content, and all legal disclaimers that apply to the journal pertain. 
Structural, morphological, and optical properties of $\mathrm{Bi}_{2} \mathrm{O}_{3}$ thin films grown by reactive sputtering

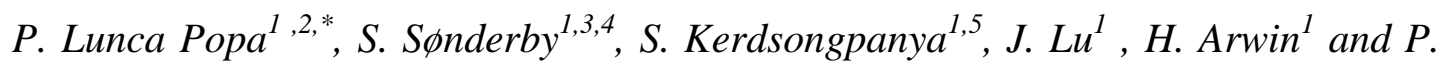
Eklund $^{1}$

${ }^{1}$ Department of Physics, Chemistry and Biology, IFM, Linköping University, SE-581

83 Linköping, Sweden

${ }^{2}$ Materials Research and Technology Department (MRT), Luxembourg Institute of Science and Technology (LIST), L-4422, Belvaux, Luxembourg

${ }^{3}$ Danish Technological Institute, Tribology Centre, Teknologiparken, Kongsvang Allé 29, DK-8000 Aarhus C, Denmark

${ }^{4}$ Present address: National Oilwell Varco Denmark I/S, Priorparken 480, DK-2605 Broendby, Denmark

${ }^{5}$ Present address: Department of Materials Science \& Engineering, Rensselaer Polytechnic Institute, Troy, NY 12180, USA

*Corresponding author. Email: petru.luncapopa@list.liu 


\begin{abstract}
$\mathrm{Bi}_{2} \mathrm{O}_{3}$ thin films were grown using reactive $\mathrm{RF}$ sputtering from a metallic Bi target. The influence of various deposition parameters (substrate temperature, applied power on target and oxygen content in the working gas) on the morphology, structure and optical properties of films was investigated. Depending on the $\mathrm{O}_{2} /\left(\mathrm{Ar}+\mathrm{O}_{2}\right)$ ratio of the working gas, bismuth, $\delta-\mathrm{Bi}_{2} \mathrm{O}_{3}, \alpha-\mathrm{Bi}_{2} \mathrm{O}_{3}$ or a mixture of these phases can be deposited, with a narrow window for growth of [111]-oriented $\delta$ $\mathrm{Bi}_{2} \mathrm{O}_{3}$ thin films. The $\delta-\mathrm{Bi}_{2} \mathrm{O}_{3}$ phase is stable from room temperature up to $350{ }^{\circ} \mathrm{C}$ (in air), where an irreversible transition to $\alpha-\mathrm{Bi}_{2} \mathrm{O}_{3}$ occurs. This phase transformation is also shown to occur during TEM sample preparation, because of the inherent heating from the ion-milling process, unless liquid-nitrogen cooling is used.
\end{abstract}

Keywords

Bismuth oxide, reactive sputtering, phase transition 


\section{Introduction}

Bismuth oxide is of interest in various technological fields as gas sensors, oxygen pumps, fuel cells and other applications where conduction by oxygen vacancies is required. $\mathrm{Bi}_{2} \mathrm{O}_{3}$ has six polymorphs: $\alpha$ (monoclinic), $\beta$ (tetragonal), $\gamma$ (cubic body-centered), $\delta$ (cubic face centered), $\varepsilon$ (orthorhombic) [1] and $\omega$ (triclinic) [2]. Among these, $\alpha$ and $\delta$ are of particular interest. The $\alpha$-phase (also called bismite) has a high refractive index and one of highest third optical non-linearity which makes it a suitable candidate for optical nonlinear devices such as wavelength converters, optical switches, ultra-short pulse generators and nonlinear optical fiber devices $[3,4]$. The $\delta$-phase is an exceptional ionic conductor, with two orders of magnitude higher ionic conductivity than that of Yttria Stabilized Zirconia (YSZ), the most used electrolyte in Solid Oxide Fuel Cells (SOFCs). The high ionic conductivity of $\delta-\mathrm{Bi}_{2} \mathrm{O}_{3}$ was attributed to the high polarizability [5] of $\mathrm{Bi}^{3+}$ ions and to the high degree of disorder [6,7] in the oxygen sub lattice in a defective fluorite structure. [8-11]. However, in bulk, the $\delta$-phase of $\mathrm{Bi}_{2} \mathrm{O}_{3}$ is stable only between $825^{\circ} \mathrm{C}$ (the melting point of bismuth oxide) and $729^{\circ} \mathrm{C}$ where it transforms into other phases with much lower ionic conductivity. This lack of stability and high temperature range constitutes a major impediment in using $\delta$ - $\mathrm{Bi}_{2} \mathrm{O}_{3}$ as electrolyte in SOFCs. Consequently, much research is focused on lowering the SOFCs operating temperature [12-16].

The stability region of $\delta-\mathrm{Bi}_{2} \mathrm{O}_{3}$ can be extended to lower temperatures by doping the $\mathrm{Bi}_{2} \mathrm{O}_{3}$ with various elements, especially lanthanides $[17,18]$ or transition metals [19-22] but this results in a large reduction in ionic conductivity, a consequence of the increasing order within unoccupied oxygen sites. A new method to stabilize the $\delta$-phase with further increase of conductivity consists in the use of highly coherent interfaces of alternating layers of $\mathrm{Er}_{2} \mathrm{O}_{3}$ stabilized $\delta$ - $\mathrm{Bi}_{2} \mathrm{O}_{3}$ and $\mathrm{Gd}_{2} \mathrm{O}_{3}$-doped $\mathrm{CeO}_{2}$. [23] 
The most used methods in the synthesis of $\mathrm{Bi}_{2} \mathrm{O}_{3}$ thin films are chemical vapor deposition [24,25], sputtering [26-30], electrodeposition [31,32], electrophoretic deposition [33] and sol gel methods [34]. There are rather few studies [24, 26,27,35] about the influence of the influence of deposition parameters onto the structure and morphology of $\mathrm{Bi}_{2} \mathrm{O}_{3}$ deposited films. In our previous work [36], we reported the synthesis of phase-pure and highly oriented $\delta-\mathrm{Bi}_{2} \mathrm{O}_{3}$ thin films stable at room temperature for a very narrow range of deposition parameters. In the present paper, we further investigate how the structure, phase composition, morphology, and optical properties of $\mathrm{Bi}_{2} \mathrm{O}_{3}$ thin films are influenced by substrate temperature, applied power on the target and the oxygen content in the working gas.

\section{Experimental procedures}

The films were grown by reactive $\mathrm{RF}$ magnetron sputtering onto $\mathrm{Si}$ (100) and $\mathrm{Al}_{2} \mathrm{O}_{3}$ (0001). Prior to deposition, the substrates were ultrasonically cleaned in acetone and isopropanol for 10 minutes and then blown-dried using nitrogen. They were inserted into the chamber mounted on a molybdenum holder with adjustable rotation speed and heated through a pyrolytic boron nitride heater. A calibration curve for substrate temperature was obtained prior to deposition by attaching an external thermocouple to an empty substrate. Heating rate was $100^{\circ} / 3 \mathrm{~min}$. The holder is positioned above the target with a cathode-to-substrate separation distance around $15 \mathrm{~cm}$. The target (Bismuth, 99.99\% purity from Mateck $\mathrm{GmbH}$ ) was mounted in a water-cooled magnetron mounted at a $45^{\circ}$ angle with respect to the rotation axis of the sample. A more detailed description of the deposition chamber can be found elsewhere [37].

The working gas was a mixture of high purity argon and oxygen. The total flux of mixed gases was 40 standard cubic centimeters per minute $(\mathrm{sccm})$ except for some control 
experiments mentioned bellow where the flow was $25 \mathrm{sccm}$. The $\mathrm{O}_{2} /\left(\mathrm{O}_{2}+\mathrm{Ar}\right)$ flow ratio was controlled by digital gas flow meters while the total pressure in the deposition chamber during deposition was monitored by a capacitance manometer (Baratron). During the sputtering process the pressure was $0.1 \mathrm{~Pa}$. The base pressure was $3 \times 10^{-6} \mathrm{~Pa}$. The sputtering was carried out with a fixed load power source (Advanced Energy RFX-600). The DC self-bias voltage on the bismuth target was constantly monitored. Before each deposition, presputtering of the target in pure argon atmosphere for 30 min was performed in order to remove the oxidized layer on the Bi target surface, and the substrates were held at the intended deposition temperature for the same time in order to achieve thermal equilibrium between the heater and the substrates. The depositions were carried out for 30 minutes (unless otherwise mentioned) corresponding to a film thickness of $300 \mathrm{~nm}$ (measured by scanning or transmission electron microscopy-SEM or TEM)

The structure of deposited films was investigated using Philips diffractometers equipped with a $\mathrm{Cu} \mathrm{K}_{\alpha} \mathrm{X}$ ray source $(\lambda=1.5406 \AA$ ) operating at $40 \mathrm{kV}$ and $40 \mathrm{~mA}$. Pole figures were acquired in azimuth angle $(\Phi)$ range $0-360^{\circ}$ and tilting angle $(\Psi)$ range of 0 $90^{\circ}$. In situ annealing measurements were performed at $5 \times 10^{-3} \mathrm{~Pa}$ with a heating rate of $50^{\circ} / \mathrm{min}$.

SEM investigations were performed in Secondary Electron mode with a system LEO 1550 using an acceleration voltage of $5 \mathrm{kV}$. TEM was performed using an analytical high resolution electron microscopy FEI Tecnai G2 TF20 UT with a field emission gun operated at $200 \mathrm{kV}$ and point resolution of $0.19 \mathrm{~nm}$. The TEM samples were prepared by gluing two pieces of samples face to face together, cutting into slice, then polishing, and finally ion milling to electron transparent. Ion milling was run at $5 \mathrm{keV}$ for an angle of $8^{\circ}$ with respect to the surface of the sample and at $2 \mathrm{keV}$ and a lower angle $\left(2^{\circ}\right)$ for the last 10 minutes. For 
some samples (mentioned in results and discussion sections) ion milling was performed with liquid nitrogen cooling in order to exclude any heating effect on the structure of the samples.

For optical measurements a dual rotating-compensator spectroscopic ellipsometer was used (RC2, J.A. Woollam Co., Inc.) in the spectral range 0.73-5.06 eV at angles of incidence $45^{\circ}, 55^{\circ}$ and $65^{\circ}$. Modeling was performed with the software CompleteEASE (J.A. Woollam Co., Inc.) in a four-layer model: $\mathrm{Si}$ substrate/4 $\mathrm{nm} \mathrm{SiO} \mathrm{S}_{2} / \mathrm{Bi}_{2} \mathrm{O}_{3}$ layer/roughness layer. Database optical data were used for $\mathrm{Si}$ and $\mathrm{SiO}_{2}$ [38]. The complex-valued dielectric function $\varepsilon=\varepsilon_{1}+i \varepsilon_{2}$ of the films were modelled with a Tauc-Lorentz dispersion model [39] providing the bandgap. Similar to the method used in ref [35] we include an additional Lorentz model to account for additional absorption bands and to improve the bandgap determination. It should be pointed out that the obtained optical properties are effective dielectric functions for a mixture of several phases, especially for the sample containing Bi. Best-fit parameters were obtained by minimizing the mean squared error (MSE) between model and experimental data. The software uses the Levenberg-Marquardt fitting algorithm and delivers best-fit parameter values and $90 \%$ confidence intervals. The confidence intervals are small indicating small correlations among fit parameters.

\section{Results and discussion}

\section{Influence of substrate temperature}

Fig. 1 shows $\theta-2 \theta$ x-ray diffractograms (Fig. 1a-e) and corresponding SEM micrographs (Fig. 1f-j) for samples grown on Si substrates at room temperature, $175{ }^{\circ} \mathrm{C}, 300$ ${ }^{\circ} \mathrm{C}, 400{ }^{\circ} \mathrm{C}$, and $500{ }^{\circ} \mathrm{C}$. All other parameters were kept the same: $30 \mathrm{~W}$ applied power on the Bi target, $40 \mathrm{sccm}$ working gas, $\mathrm{O}_{2} /\left(\mathrm{O}_{2}+\mathrm{Ar}\right)$ ratio $20 \%$. The DC self-bias was $-120 \mathrm{~V}$ for all depositions. Fig. 1a, corresponding to the sample deposited at room temperature, shows only a 
broad feature centered on $2 \theta=27^{\circ}$, indicating an X-ray amorphous film, as expected at room temperature. The sharp peak at $2 \theta=33^{\circ}$ is the Si substrate 200 peak. The corresponding SEM image (Fig. 1f) shows a uniform deposit, with elongated islands with length around $50 \mathrm{~nm}$ and width below $10 \mathrm{~nm}$.

The films deposited at $175^{\circ} \mathrm{C}$ consist of a mixture of bismuth and $\alpha-\mathrm{Bi}_{2} \mathrm{O}_{3}$ phases; the following peaks could be identified [40,41] (Fig. 1b) : Bi $003\left(2 \theta=22.5^{\circ}\right), 006\left(2 \theta=45.9^{\circ}\right)$, $\mathbf{0 1 2}\left(2 \theta=27.2^{\circ}\right), \mathbf{0 2 4}\left(2 \theta=56.0^{\circ}\right), \mathbf{1 1 0}\left(2 \theta=39.7^{\circ}\right) ; \alpha-\mathrm{Bi}_{2} \mathrm{O}_{3} \mathbf{0 1 2}\left(2 \theta=28.0^{\circ}\right), \mathbf{0 2 4}\left(2 \theta=57.8^{\circ}\right) \mathbf{1 1 2}$ $\left(2 \theta=37.9^{\circ}\right), \mathbf{3 0 2}\left(2 \theta=44.6^{\circ}\right)$ and $142\left(2 \theta=51.3^{\circ}\right)$. This phase-mixture can be observed also in the corresponding SEM micrograph (Fig. 1g) where small circular islands (bright spots with diameter $\approx 30 \mathrm{~nm}$ ) are randomly distributed over a predominant phase consisting of irregular larger grains $(\approx 100-150 \mathrm{~nm})$.

The morphology of the films changes dramatically when the substrate temperature is increased above $300^{\circ} \mathrm{C}$ (Fig. 1c). Besides the peaks corresponding to Bi 012, $024\left(2 \theta=27.2^{\circ}\right.$ and $\left.56.0^{\circ}\right)$ and to $\alpha-\mathrm{Bi}_{2} \mathrm{O}_{3} \mathbf{0 1 2}, \mathbf{0 2 4}\left(2 \theta=28.0^{\circ}\right.$ and $\left.57.8^{\circ}\right)$, a new strong peak appears at $2 \theta=25.8^{\circ}$ which can be attributed to $\alpha-\mathrm{Bi}_{2} \mathrm{O}_{3}$ 002. At this temperature, the bismuth adatom mobility is high and thus probability for oxide formation increases, explaining why $\alpha$-phase is predominant. For these samples crystalline grains are clearly defined and two different phases are distinguished easily (Fig. 1h). The SEM micrograph shows a mixture of two phases: a minor one (bismuth) formed by small, almost pentagonal shaped islands, having a size around $200 \mathrm{~nm}$ surrounded by a second compact phase $(\alpha)$.

For films deposited at a substrate temperature of $400{ }^{\circ} \mathrm{C}$, the XRD scan (Fig. 1d) shows mainly same peaks as in previous case but with different intensity ratios. The corresponding micrograph (Fig. 1i) illustrates a similar mixture of two phases but now with comparable grain sizes. By further increasing the temperatures up to $500{ }^{\circ} \mathrm{C}$ only $\mathrm{Bi} \mathbf{0 1 2}$ and a faint $\alpha \mathbf{0 1 2}$ peak are still observable (Fig. 1e). Moreover, a peak appears at $2 \theta=29.2^{\circ}$ which 
possibly corresponds to nonstoichiometric bismuth oxide. The corresponding micrograph seems to indicate the presence of only one phase in scanned areas (Fig. 1j). With the increase of substrate temperature from room temperature to $175^{\circ} \mathrm{C}$, the surface mobility of adatoms increases. As shown by the XRD results, besides bismuth, only $\alpha$-phase is forming in these conditions. The loss of growth of $\alpha$-phase at a temperature around $500^{\circ} \mathrm{C}$ cannot be explained by increased strain with temperature as the expansion coefficients are similar (Bi 13.4 and $\alpha$ $\mathrm{Bi}_{2} \mathrm{O}_{3} \approx 1410^{-6} /{ }^{\circ} \mathrm{C}$; for $\mathrm{Si} \approx 310^{-6} /{ }^{\circ} \mathrm{C}$ for this temperature range) but rather by the fact that $\alpha$-phase is thermodynamically stable at lower temperatures [42].

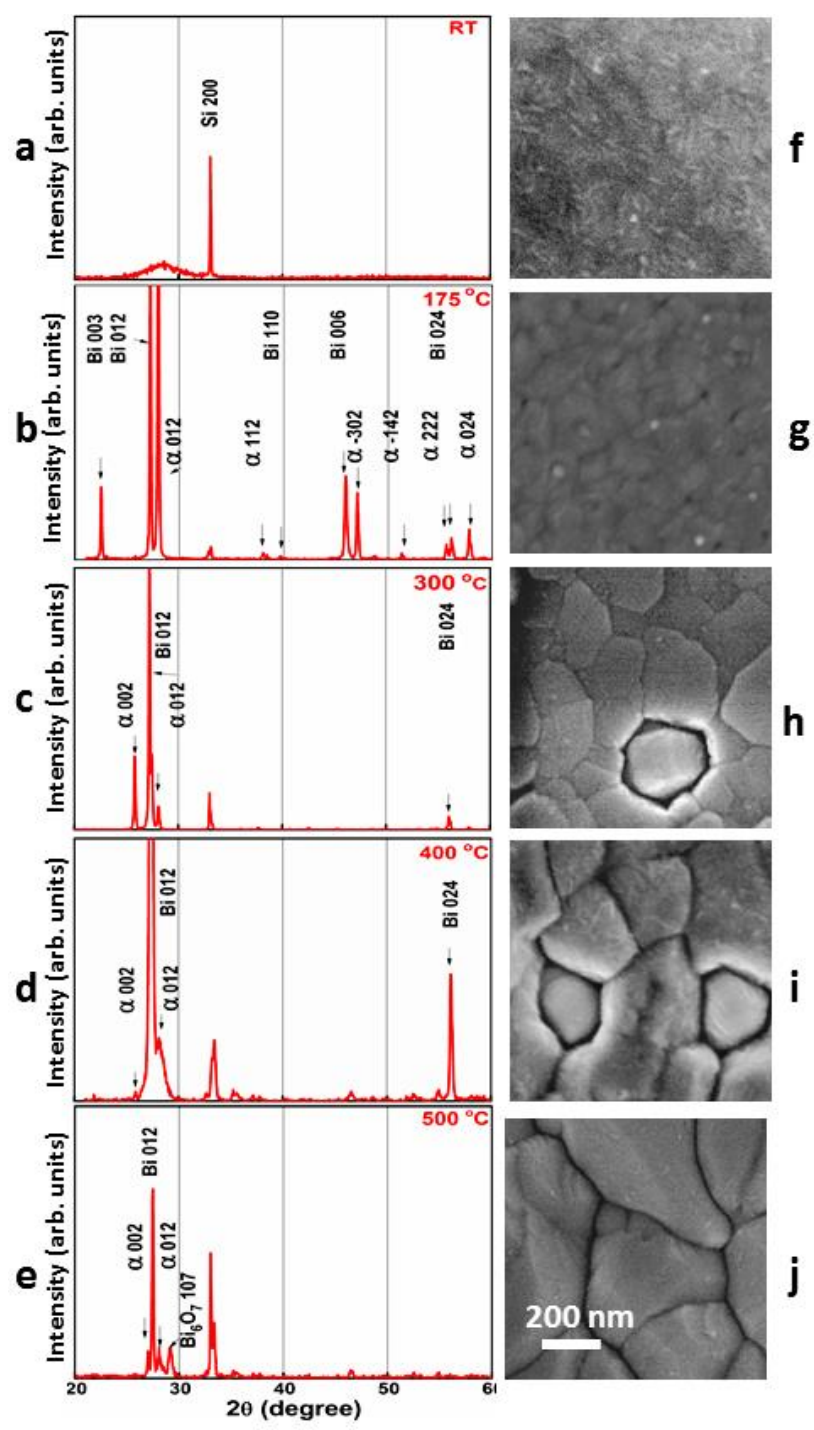


Fig.1 X-ray diffractograms (a-e) and SEM micrographs (f-j) for samples deposited onto Si 100 substrates at different temperatures. Peak intensities in arbitrary units. The horizontal bar is 200 $\mathrm{nm}$, valid for all micrographs

\section{Influence of oxygen content in the working gas}

The results of the investigations related to oxygen ratio content in the total workinggas flow are shown in Fig. 2 (XRD patterns in Figs. 2a-f and corresponding SEM images in Figs. 2 g-1). Other deposition parameters are kept at constant values: RF power $20 \mathrm{~W}$, substrate temperature $175^{\circ} \mathrm{C}$. All films are deposited on Si 100 substrates (hence the Si 200 peak $2 \theta=33.0^{\circ}$ present in all diffractograms).

At an $\mathrm{O}_{2} /\left(\mathrm{O}_{2}+\mathrm{Ar}\right)$ ratio of $2.5 \%$ (Fig. 2 a), the oxygen content is too low to form oxides and metallic bismuth is predominant. The diffraction peaks can be attributed to Bi: $\mathbf{0 1 2}$ $\left(2 \theta=27.2^{\circ}\right), \mathbf{0 2 4}\left(2 \theta=56.0^{\circ}\right), 104\left(2 \theta=38.0^{\circ}\right)$ and $116\left(2 \theta=62.2^{\circ}\right)$ while the peak from $2 \theta=27.95^{\circ}$ can be attributed either to $\alpha-\mathrm{Bi}_{2} \mathrm{O}_{3} \mathbf{0 1 2}$ or $\delta-\mathrm{Bi}_{2} \mathrm{O} \mathbf{1 1 1}$ (see section below). The corresponding SEM image (Fig. 2g) shows a uniform deposit with a granular structure, with grain size about $150-200 \mathrm{~nm}$. Small bright spots with diameter below $30 \mathrm{~nm}$, uniformly distributed, can be observed. When the oxygen ratio in the working gas flow is increased to $5 \%$, more peaks appear in the diffractogram (Fig. 2b). Besides the previous Bi peaks, new ones are observed at $2 \theta=39.8^{\circ}(\mathbf{1 1 0})$ and $2 \theta=44.5^{\circ}(\mathbf{0 1 5})$. More peaks which can be attributed to nonstoichiometric $\mathrm{Bi}_{2} \mathrm{O}_{2.75} 2 \theta=44.5^{\circ}$ (114) and $2 \theta=47.1^{\circ}$ (200) [43]. The film is uniform and compact, with irregular grain size (Fig. $2 \mathrm{~h}$ ). When oxygen ratio further increases to $15 \%$ (Fig. 2c) and then to $17.5 \%$ (Fig. 2d), the conditions become more favorable for formation of $\delta-\mathrm{Bi}_{2} \mathrm{O}_{3}$. The corresponding peak $\delta-\mathrm{Bi}_{2} \mathrm{O} 111\left(2 \theta=27.95^{\circ}\right)$ becomes more intense while those belonging to bismuth phase become weaker. Moreover the $\delta-\mathrm{Bi}_{2} \mathrm{O} 222\left(2 \theta=57.7^{\circ}\right)$ peak appears. The corresponding SEM micrographs (Fig. 2i and j) indicate uniform films with 
grains size decreasing with the increase concentration of oxygen. This tendency goes until the complete disappearance of $\mathrm{Bi}(\mathrm{Fig} .2 \mathrm{e})$ for $\mathrm{O}_{2} /\left(\mathrm{O}_{2}+\mathrm{Ar}\right)=20 \%$ when the films are formed only by a highly textured $\delta-\mathrm{Bi}_{2} \mathrm{O}_{3}$ with a preferential direction growth along [111] (see also pole figures, TEM investigations and discussion in the sections below). Both $\mathbf{1 1 1}$ and 222 peaks are clearly defined now and no others peaks are present. By increasing the oxygen flow ratio to $25 \%$ (Fig. $2 \mathrm{f}$ and 21$)$ the $\mathrm{BiO}$ phase of appears: $\mathbf{0 0 3}\left(2 \theta=27.53^{\circ}\right), \mathbf{1 0 1}\left(2 \theta=28.2^{\circ}\right), \mathbf{0 0 6}$ $\left(2 \theta=56.83^{\circ}\right)$ and $202\left(2 \theta=58.4^{\circ}\right)$. As shown by the SEM micrographs, when increasing oxygen content the films become denser and with smaller grains sizes. 


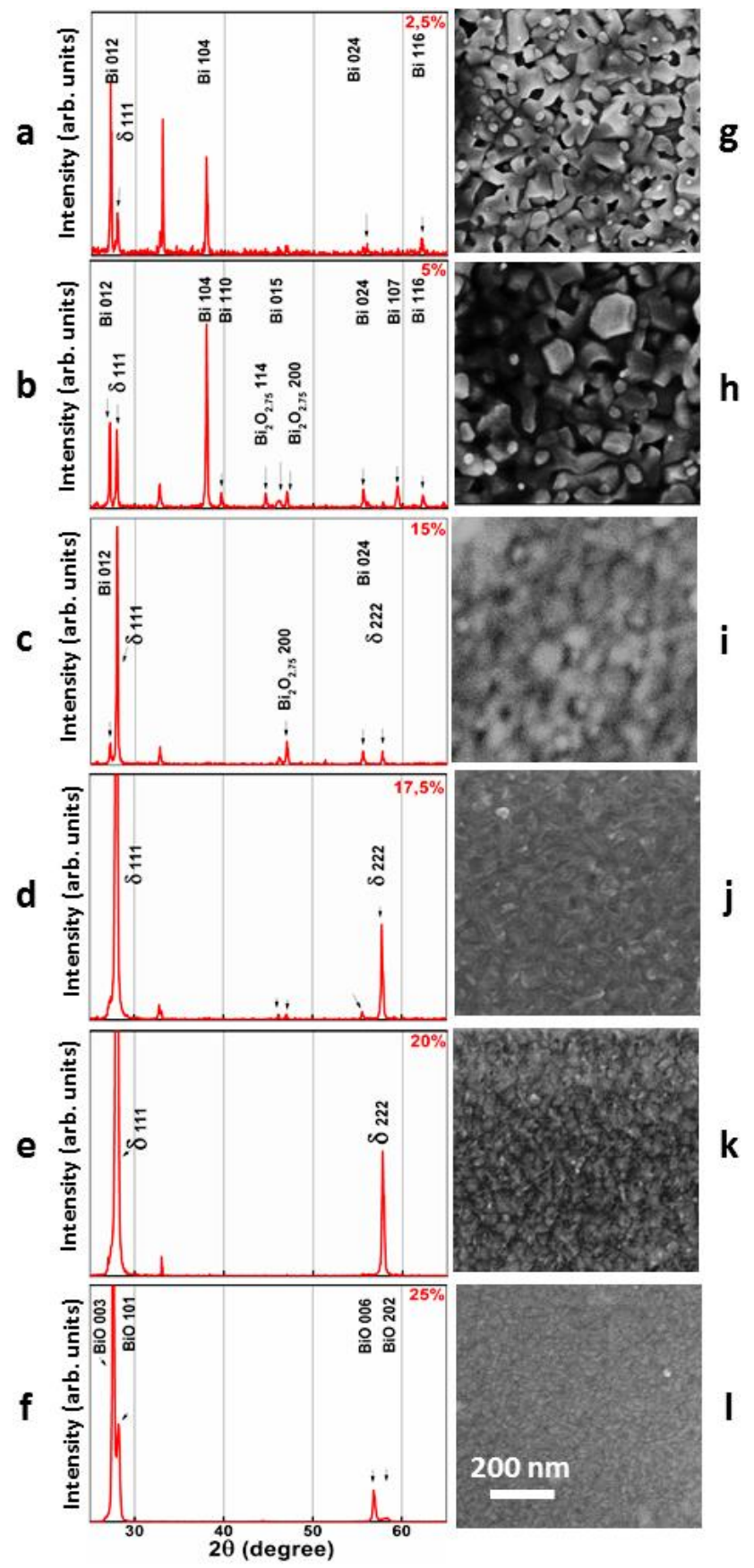

Fig.2 XRD scans (a-f) and SEM micrographs (g-l) for films deposited at different $\mathrm{O}_{2} /\left(\mathrm{O}_{2}+\mathrm{Ar}\right)$ ratios. Other deposition parameters are kept at same values: $\mathrm{RF}$ power $20 \mathrm{~W}$, substrate temperature $175^{\circ} \mathrm{C}, 40 \mathrm{sccm}$ work gas flow. The horizontal bar is $200 \mathrm{~nm}$, valid for all micrographs 


\section{Influence of power applied on target}

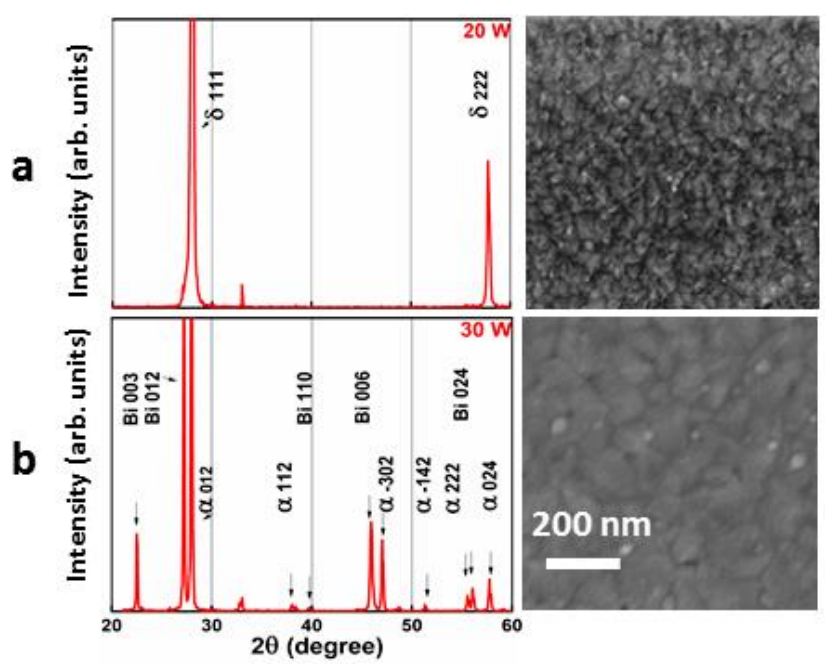

Fig. 3 Influence of applied power on target. XRD and SEM micrograph for a sample fabricated using: $\mathrm{a}-20 \mathrm{~W}$; and $\mathrm{b}-30 \mathrm{~W}$. The horizontal bar is $200 \mathrm{~nm}$

The results for two films deposited at different applied powers (20 $\mathrm{W}$ and $30 \mathrm{~W}$ ) are shown in Fig. 3. The other parameters were kept fixed at the following values: substrate temperature $175{ }^{\circ} \mathrm{C}$, working gas flow $40 \mathrm{sccm}$ and the $\mathrm{O}_{2} /\left(\mathrm{O}_{2}+\mathrm{Ar}\right)$ ratio was $20 \%$. There are substantial differences related to the structure of as deposited films. For $20 \mathrm{~W}$ applied power, the films consist of highly textured pure $\delta-\mathrm{Bi}_{2} \mathrm{O}_{3}$ with a preferential direction of growth along 111. When the power is increased to $30 \mathrm{~W}$ the films become a mixture of $\mathrm{Bi}$ and $\alpha-\mathrm{Bi}_{2} \mathrm{O}_{3}$. This is expected assuming that the amount of sputtered Bi atoms scales approximately linearly with the applied target power, rendering the resulting films sub-stoichiometric in oxygen (with respect to the overall film composition). The degree of orientation is decreasing although some preferential directions of growth are still observed for both components (003 and 012 for $\mathrm{Bi} ; \mathbf{0 1 2}$ for $\alpha-\mathrm{Bi}_{2} \mathrm{O}_{3}$ ). An increase of the film density with increasing power is observed in corresponding SEM micrographs. The mixture of bismuth and $\alpha-\mathrm{Bi}_{2} \mathrm{O}_{3}$ is observed also in the micrograph in Fig. $3 b$ (corresponding to a power of $30 \mathrm{~W}$ ): $\alpha$-phase has a uniform structure while the bismuth is randomly distributed in small islands (brighter spots). 
The results of ellipsometry measurements for the films deposited at $20 \mathrm{~W}$ and $30 \mathrm{~W}$ power are shown in Fig. 4 and Table 1. The film deposited at $30 \mathrm{~W}$ was found to be $42 \%$ thicker which is expected as deposition rate scales approximately linearly with applied power. The film synthesized at higher power has a lower roughness, possibly because of leveling of the surface due to incident higher-energy species. The $\delta-\mathrm{Bi}_{2} \mathrm{O}_{3}$ films have an optical band gap of around $2.4 \mathrm{eV}$ which is in accordance with Fan et al. who reported $2.45 \mathrm{eV}$ [27]. For the $\mathrm{Bi}+\alpha-\mathrm{Bi}_{2} \mathrm{O}_{3}$ film, the band gap becomes smaller and is around $1.9 \mathrm{eV}$ for this film. This is lower than $2.5-2.8 \mathrm{eV}$ previously reported for the $\alpha$-phase [44], most likely due to the fact that the films contain a minority phase of metallic bismuth. The dispersion curves for the refractive index and extinction coefficient are similar of those obtained by Gomez et al. [35]. However, our films have slightly higher refractive indices, possibly indicating that they are denser. Similarly to Gomez et al., we have included an interband transition. To reduce the correlation parameter we use only one transition with energy as shown in Table 1. This increases modeling accuracy for bandgap determination but the values of the interband transitions are only indicative and further studies are needed to fully characterize these resonances. We also observe that the fit to the model is better for the $\delta$-phase as the MSE is lower for this sample.

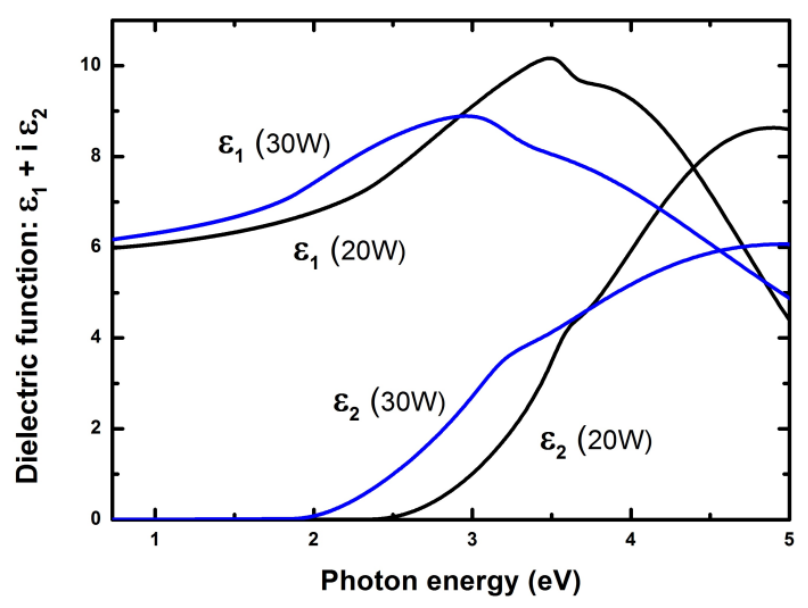


Fig. 4 Dielectric function $\varepsilon=\varepsilon_{1}+i \varepsilon_{2}$ as determined from analysis of ellipsometry data recorded on $\mathrm{Bi} 2 \mathrm{O} 3$ films using $20 \mathrm{~W}$ (black curve) and $30 \mathrm{~W}$ (blue curve) applied power on the target

Table 1. Ellipsometry results for two films grown using two different RF applied powers

\begin{tabular}{lcc}
\hline Film & $\boldsymbol{\delta}-\mathrm{Bi}_{2} \mathbf{O}_{3}$ & $\mathbf{B i}+\boldsymbol{\alpha}-\mathbf{B i}_{2} \mathbf{O}_{3}$ \\
\hline RF power (W) & 20 & 30 \\
\hline Surface roughness $(\mathrm{nm})$ & $4.9 \pm 0.1$ & $2.7 \pm 0.1$ \\
\hline Layer thickness $(\mathrm{nm})$ & $298.0 \pm 0.1$ & $423.2 \pm 0.1$ \\
\hline Band gap (eV) & $2.360 \pm 0.002$ & $1.862 \pm 0.003$ \\
\hline Interband (eV) & 3.59 & 3.21 \\
\hline MSE & 3.5 & 8.2 \\
\hline
\end{tabular}

\section{Deposition of $\delta-\mathrm{Bi}_{2} \mathrm{O}_{3}$ thin films}

As described in our previous paper [36] and briefly summarized here for completeness, highly oriented pure $\delta-\mathrm{Bi}_{2} \mathrm{O}_{3}$ films can be deposited both on silicon and sapphire substrates for a very narrow range of deposition parameters $\left(150-200^{\circ} \mathrm{C}, 18 \%-20 \%\right.$ of $\mathrm{O}_{2} /\left(\mathrm{O}_{2}+\mathrm{Ar}\right)$ ratio in the sputtering gas and $20 \mathrm{~W}$ applied power on target). Fig. 5 a (from Ref. 36) shows XRD patterns for films deposited in same batch onto $\mathrm{Si}$ and $\mathrm{Al}_{2} \mathrm{O}_{3}$. Beside the peaks characteristic to the substrates $\mathrm{Si} 200\left(2 \theta=33.1^{\circ}\right), \mathrm{Si} 400\left(2 \theta=69.2^{\circ}\right), \mathrm{Al}_{2} \mathrm{O}_{3} 006$ $\left(2 \theta=42.0^{\circ}\right)$ there two more peaks at $2 \theta$ positions $28.0^{\circ}$ and $57.4^{\circ}$. Monoclinic alpha [40], tetragonal beta [45] and cubic delta [46] phases of $\mathrm{Bi}_{2} \mathrm{O}_{3}$ present all very close diffraction peaks around these $2 \theta$ positions and thus for a precise phase identification a XRD texture analysis was performed (Fig. 5.b, from Ref. [36]). The diffraction rings observed at $\Psi=70^{\circ}$ 
$\left(2 \theta=28.0^{\circ}\right), \Psi=54^{\circ}\left(2 \theta=32.4^{\circ}\right)$ and $\Psi=35^{\circ}\left(2 \theta=46.6^{\circ}\right)$ prove the cubic crystal geometry of films and hence the presence of $\delta-\mathrm{Bi}_{2} \mathrm{O}_{3}$.

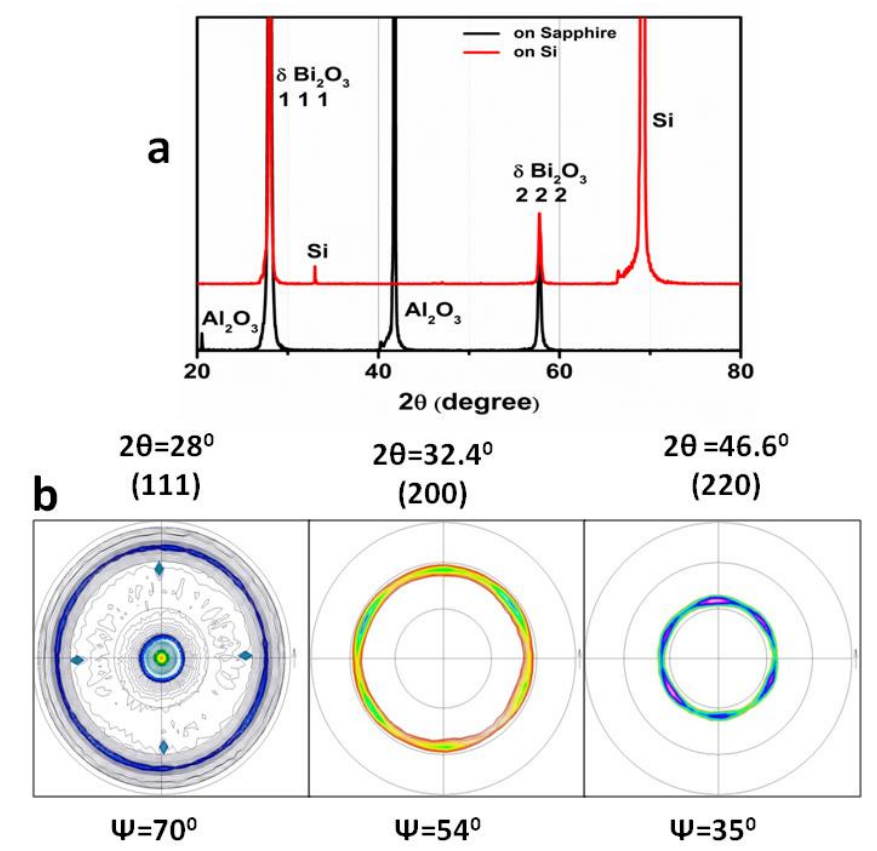

Fig.5 (From Ref. 36) $\delta-\mathrm{Bi}_{2} \mathrm{O}$ films. a XRD $\theta-2 \theta$ patterns for films deposited onto $\mathrm{Si}(100)$ (red) and $\mathrm{Al}_{2} \mathrm{O}_{3}(0001)$ (black) substrates; $\mathbf{b}$ pole figures for $2 \theta$ positions of $28^{\circ}, 32.4^{\circ}$ and $44.6^{\circ}$.

Two important observations in the effort to explain the formation of $\delta-\mathrm{Bi}_{2} \mathrm{O}_{3}$ in these conditions: this phase is obtained in a very narrow window of deposition parameters values and it exhibits higher thermal stability in air than in vacuum [36]. First, there is competition between the thermodynamics of the process and the surface kinetics, meaning that formation of $\delta$-phase with its simpler cubic stacking (compared to monoclinic $\alpha$-phase) is kinetically favored at substrate temperature of around $200{ }^{\circ} \mathrm{C}$. Second, the $\delta$-phase can accommodate a degree of vacancies on oxygen sites and therefore provides a mechanism for increased stability relative to the $\alpha$-phase.

After this summary of the results from Ref. 36, we proceed with further TEM characterization. Figure 6 shows TEM images for two $\mathrm{Bi}_{2} \mathrm{O}_{3}$ films from the same deposition batch, both exhibiting $\delta-\mathrm{Bi}_{2} \mathrm{O}_{3}$ films in the as-deposited state. For the first film, liquid 
nitrogen cooling was used during the ion milling process (Fig. 6a from Ref. [36]). It has a columnar structure with thickness of $300 \mathrm{~nm}$ and $\sim 50 \mathrm{~nm}$ column diameter. HRTEM and SAED images indicate a highly textured film with a preferential growth direction along [111]. However, an important result is observed for samples that were prepared with ion milling without any cooling: after TEM sample preparation, the films now present a monoclinic $\alpha$ structure (Fig. 6 b). This shows that the inherent heating from the ion-milling process exceeds the temperature required to transform the samples from $\delta$ to $\alpha$; for ex-situ annealing, the $\delta-\alpha$ phase transition was observed to take place around $260^{\circ} \mathrm{C}$. The volume of the $\alpha$ crystal is noteworthy, as only one crystalline grain can be observed in the TEM images, i.e., the observed $\alpha$ grain covers the entire film thickness and is at least $300 \mathrm{~nm}$ wide (the limits of electron transparency of the TEM sample. These results show that the inherent heating of the ion-milling process transfers sufficient energy to the film to transform from the metastable $\delta$ phase into the more thermodynamically stable $\alpha$-phase. As further supported by our previous annealing experiments [36], this transition is affected by the surrounding environment, as we observed for ex-situ annealing experiments (i.e. in atmospheric conditions) the transition taking place around $350{ }^{\circ} \mathrm{C}$ while for in-situ annealing in vacuum, the same transition was observed around $260^{\circ} \mathrm{C}$.

These results emphasize the need for care during sample preparation not only of $\delta$ $\mathrm{Bi}_{2} \mathrm{O}_{3}$, but also more generally for metastable materials with a stability limit in the same range as the inherent heating caused by the ion-milling process. 


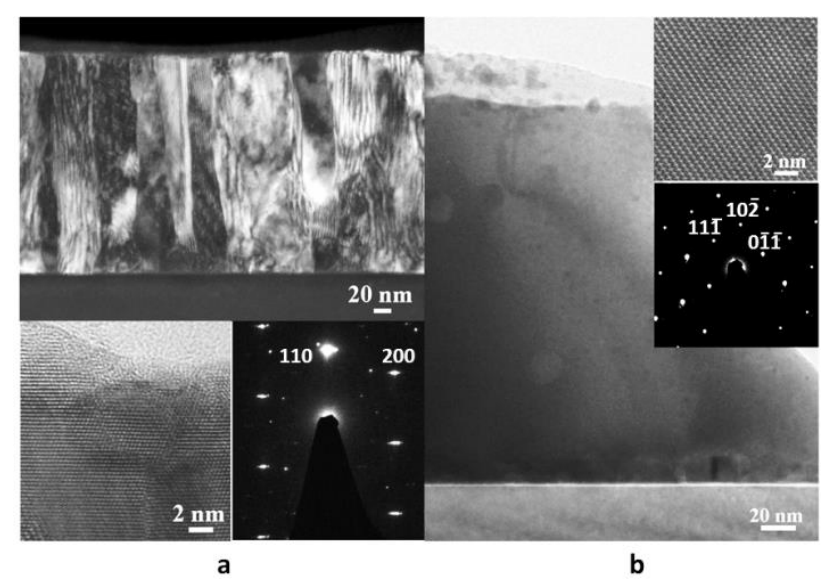

Fig.6 TEM investigations on $\delta-\mathrm{Bi}_{2} \mathrm{O}_{3}$ samples a (from Ref. 36) TEM, HRTEM and SAED images for a sample prepared using nitrogen cooling during ion milling process. b. TEM, HRTEM and SAED for a sample prepared using normal ion milling.

\section{V.CONCLUSIONS}

$\mathrm{Bi}_{2} \mathrm{O}_{3}$ films were synthesized by $\mathrm{RF}$ reactive sputtering and the influence of substrate temperature, applied power on target and oxygen content in the working gas on the structure morphology and optical properties of the films was investigated. The main effect of substrate temperature is the changing grain size due to different bismuth adatoms mobility on the surface. Both applied power and oxygen content alter the oxygen/bismuth ratio. $\underline{B y}$ changing any parameter related to this ratio a change in the properties of the films is obtained. There is a narrow process window where highly oriented phase-pure $\delta-\mathrm{Bi}_{2} \mathrm{O}_{3}$ films are obtained. These are stable to $260{ }^{\circ} \mathrm{C}$ (in vacuum) or $350{ }^{\circ} \mathrm{C}$ (in atmosphere) before transforming to $\alpha$-phase. This phase transformation can also occur during TEM sample preparation, because the inherent heating from the ion-milling process exceeds the temperature required to transform the samples from $\delta$ to $\alpha$-phase. This emphasizes the need for care in sample preparation also more generally for metastable materials. 


\section{Acknowledgments}

We acknowledge support from the Swedish Foundation for Strategic Research (Future Research Leaders 5), Nordforsk Ref. No. 9046 (ThinSOFT), Nordic Innovation Centre Ref. No. 09046 (Thin-SOFC), the European Research Council (ERC) under the European Community's Seventh Framework Programme (FP/2007-2013)/ERC Grant Agreement No. 335383, and the Swedish Research Council (VR) under Project No. 20124430.

\section{References}

[1] N. Cornei, N. Tancret, F. Abraham, O. Mentré, New $\varepsilon-\mathrm{Bi}_{2} \mathrm{O}_{3}$ Metastable Polymorph, Inorg. Chem, 45, 2006, 4886.

[2] A.F. Gualtieri, S. Immovilli, M. Prudenziati, Powder X-ray diffraction data for the new polymorphic compound $\omega-\mathrm{Bi}_{2} \mathrm{O}_{3}$, J. Powder Diffraction 12, 1997, 90.

[3] T. Hasegawa, T. Nagashima, N. Sugimoto, Z-scan study of third-order optical nonlinearities in bismuth-based glasses, Optics Communications 250, 2000, 411.

[4] T. Hasegawa, Optical properties of $\mathrm{Bi}_{2} \mathrm{O}_{3}-\mathrm{TeO}_{2}-\mathrm{B}_{2} \mathrm{O}_{3}$ glasses, Journal of Non-Crystalline Solids 357, 2011, 2857.

[5] D.S. Aidhy, S.B. Sinnott, E.D. Wachsman, S.R. Phillpot, Effect of ionic polarizability on oxygen diffusion in $\delta-\mathrm{Bi}_{2} \mathrm{O}_{3}$ from atomistic simulation, Ionics 16, 2010, 297.

[6]D. Shuk, H.D. Wiemhöfer, U. Guth, W. Göpel, M. Greenblatt, Oxide ion conducting solid electrolytes based on $\mathrm{Bi}_{2} \mathrm{O}_{3}$, Solid State Ionics 89, 1996, 179.

[7]C.E. Mohn, S. Stølen,S. T. Norberg, S. Hull, Oxide-ion disorder within the high temperature delta phase of $\mathrm{Bi}_{2} \mathrm{O}_{3}$, Phys. Rev. Lett. 102, 2009, 155502.

[8] D.S. Aidhy, S.B. Sinnott, E D. Wachsman, S.R. Phillpot, J.C. Nino, Structure of $\delta-\mathrm{Bi}_{2} \mathrm{O}_{3}$ from density functional theory: A systematic crystallographic analysis, Journal of Solid State Chem. 182, 2009, 1222. 
[9] N.M. Sammes, G.A. Tompsett, H. Näfe, and F. Aldinger, Bismuth based oxide electrolytes - structure and ionic conductivity, Journal of the European Ceramic Society 19, 1999, 1801.

[10] A. Matsumoto, Y.Koyama, I.Tanaka, Structures and energetics of $\mathrm{Bi}_{2} \mathrm{O}_{3}$ polymorphs in a defective fluorite family derived by systematic first-principles lattice dynamics calculations, Phys.Rev. B 81, 2010, 094117.

[11] S. Hull, S. Norberg, M.G. Tucker, S.G. Eriksson, C.E. Mohn , S. Stolen, Neutron total scattering study of the $\delta$ and $\beta$ phases of $\mathrm{Bi}_{2} \mathrm{O}_{3}$, Dalton Trans. 40, 2009, 8737.

[12] K.T. Lee, H. S. Yoon and E.D. Wasmann, The evolution of low temperature solid oxide fuel cells, J. Mater Res. 27, 2012, 2063.

[13] M. Tsuchiya, B.-K. Lai and S. Ramanathan, Scalable nanostructured membranes for solidoxide fuel cells, Nature Nanotechnology 6, 2011, 282.

[14] K. Kerman, B.-K. Lai and S. Ramanathan, Nanoscale Compositionally Graded Thin-Film Electrolyte Membranes for Low-Temperature Solid Oxide Fuel Cells, Adv.Energy Mater. 2, 2012, 656.

[15] E. D. Wachsman and K. T. Lee Lowering the temperature of solid oxide fuel cells, Science 334, 2011, 935 .

[16] B.C.H. Steele and A. Heinzel, Materials for fuel-cell technologies, Nature 414, 2001, 345.

[17] S.H. Jung, E.D. Wachsman, and N. Jiang, Structural Stability and Conductivity of $\left(\mathrm{WO}_{3}\right)_{\mathrm{x}}\left(\mathrm{Dy}_{2} \mathrm{O}_{3}\right)_{\mathrm{y}}\left(\mathrm{Bi}_{2} \mathrm{O}_{3}\right)_{1-\mathrm{x}-\mathrm{y}}$, , Ionics 8, 2002, 210.

[18] Durmuş, V. Çorumlu, T. Çifci, I. Ermis, M. Arı, Electrical, structural and thermal properties of nanoceramic $\left(\mathrm{Bi}_{2} \mathrm{O}_{3}\right)_{1-\mathrm{x}-\mathrm{y}}\left(\mathrm{Ho}_{2} \mathrm{O}_{3}\right)_{\mathrm{x}}\left(\mathrm{Tm}_{2} \mathrm{O}_{3}\right)_{\mathrm{y}}$ ternary system, Ceram. Int. 39, 2013, 5241.

[19] C.L. Gomez, O. Depablos-Rivera, J.C. Medina, P. Silva-Bermudez S. Muhl, A. Zeinert, S. E. Rodil, Stabilization of the delta-phase in $\mathrm{Bi}_{2} \mathrm{O}_{3}$ thin films, Solid State Ionics 255, 2014, 147.

[20] C.D. Ling, R.L.Withers, S. Schmid, J.G. Thompson, A Review of Bismuth-Rich Binary Oxides in the Systems $\mathrm{Bi}_{2} \mathrm{O}_{3}-\mathrm{Nb}_{2} \mathrm{O}_{5}, \mathrm{Bi}_{2} \mathrm{O}_{3}-\mathrm{Ta}_{2} \mathrm{O}_{5}, \mathrm{Bi}_{2} \mathrm{O}_{3}-\mathrm{MoO}_{3}$, and $\mathrm{Bi}_{2} \mathrm{O}_{3}-\mathrm{WO}_{3}$, J. Solid State Chem. 137, $1998,42$. 
[21] M. Struzik, X. Liu, I. Abrahams, F. Krok, M. Malys, J.R. Dygas, Defect structure and electrical conductivity in the pseudo-binary system $\mathrm{Bi}_{3} \mathrm{TaO}_{7}-\mathrm{Bi}_{3} \mathrm{NbO}$, Solid State Ionics 218, 2012, 25.

[22] G. Szwachtaa, S. Kąc, T. Moskalewicz, Structure and thermal stability of $\mathrm{Bi}_{3} \mathrm{NbO}_{7}$ thin films grown by pulsed laser deposition, Surface and Coatings Technology 302, 2016, 474.

[23] S. Sanna, V. Esposito, J. W. Andreasen, J. Hjelm, W. Zhang, T. Kasama, S. Bredmose Simonsen, M.Christensen, S. Linderoth and N. Pryds, Enhancement of the chemical stability in confined $\delta$-Bi2O3 Nature Materials 14, 2015, 500.

[24] T. Takeyama, N. Takahashi, T. Nakamura, S. Itoh, Growth and characterization of high-quality $\delta$ $\mathrm{Bi}_{2} \mathrm{O}_{3}$ thin films grown by carbothermal evaporation, Mat. Lett. 60, 2006, 1733.

[25] T. Takeyama, N. Takahashi, T. Nakamura, S. Itoh, $\delta-\mathrm{Bi}_{2} \mathrm{O}_{3}$ thin films deposited on dense YSZ substrates by CVD method under atmospheric pressure for intermediate temperature SOFC applications, Surface and Coatings Technology 200, 2006, 4797.

[26] L.-C. Tien, Y.-H. Liou, Synthesis of $\mathrm{Bi}_{2} \mathrm{O}_{3}$ nanocones over large areas by magnetron sputtering, Surface and Coatings Technology 265, 2015, 1.

[27] H.T. Fan, X.M. Teng, S.S. Pan, C. Ye, G. H. Li, and L.D. Zhang, $\delta-\mathrm{Bi}_{2} \mathrm{O}_{3}$ thin films prepared by reactive sputtering: Fabrication and characterization, Thin Solid Films 513, 2006, 142.

[28] ] H.T. Fan, X.M. Teng, S.S. Pan, C. Ye, G.H. Li, and L.D. Zhang, Optical properties of $\delta-\mathrm{Bi}_{2} \mathrm{O}_{3}$ thin films grown by reactive sputtering, Applied Physics Letters 87, 2005, 231916.

[29] J. Morasch, S. Li, J. Brötz, W. Jaegermann and A. Klein, Reactively magnetron sputtered $\mathrm{Bi}_{2} \mathrm{O}_{3}$ thin films: Analysis of structure, optoelectronic, interface, and photovoltaic properties, Phys. Status Solidi A 211, 2014, 93.

[30] J.C. Medina, M. Bizarro, C.L. Gomez, O. Depablos-Rivera, R. Mirabal-Rojas, B.M. Monroy, A. Fonseca-Garcia, J. Perez-Alvarez, S.E. Rodil, Sputtered bismuth oxide thin films as a potential photocatalytic material, Catalysis Today 266, 2016, 144.

[31] J.A. Switzer, M.G. Shumsky, E.W. Bohannan, Electrodeposited Ceramic Single Crystals Science 284, 1999, 293. 
[32] N.V. Skorodumova, A.K. Jonsson, M. Herranen, M. Strømme, G.A. Niklasson, B. Johansson, S.I. Simak, Random conductivity of $\delta-\mathrm{Bi}_{2} \mathrm{O}_{3}$ films, Appl. Phys. Lett. 86, 2005, 241910.

[33] D. Zhang and Q. Xiang, Green electrophoretic deposition of Bi2O3 coating, Journal of Materials Science: Materials in Electronics, first online July 2016, 1.

[34] X. Xiaohong, Q.Wei, H. Weidong The photocatalytic properties of bismuth oxide films prepared through the sol-gel method, J. Molecular Catalysis A: Chemical 261, 2007, 167.

[35] C.L. Gomez, O. Depablos-Rivera ,P. Silva-Bermudez , S. Muhl, A. Zeinert, M. Lejeune,S. Charvet, P. Barroy, E.Camps, S.E. Rodil , Opto-electronic properties of bismuth oxide films presenting different crystallographic phases, Thin Solid Films 578, 2015, 103.

[36] P. Lunca Popa, S. Sonderby, S. Kerdsongpanya, J. Lu, N. Bonanos and P. Eklund, Highly oriented $\delta-\mathrm{Bi}_{2} \mathrm{O}_{3}$ thin films stable at room temperature synthesized by reactive magnetron sputtering, J. Appl. Phys. 113, 2013, 046101.

[37] J. Frodelius, P. Eklund, M. Beckers, P.O.Å. Persson, P. Eklund, L. Hultman, H. Högberg and L. Hultman, Sputter deposition from a $\mathrm{Ti}_{2} \mathrm{AlC}$ target: Process characterization and conditions for growth of $\mathrm{Ti}_{2} \mathrm{AlC}$, Thin Solid Films 518, 2010, 1621.

[38] C.M. Herzinger, B. Johs, W.A. McGahan and J.A. Woollam, Ellipsometric determination of optical constants for silicon and thermally grown silicon dioxide via a multi-sample, multiwavelength, multi-angle investigation, J. Appl. Phys. 83, 1998, 3323.

[39] G.E. Jellison, Jr. and F.A. Modine, Parameterization of the optical functions of amorphous materials in the interband region, Appl. Phys. Lett. 69, 1996, 371.

[40] ICDD PDF Card 041-1449

[41] ICDD PDF Card 085-1329

[42] A. Walsh, G.W. Watson, D.J. Payne, R.G. Edgell, J. Guo, P.-A. Glans, T. Learmonth, and K.E. Smith, Electronic structure of the $\alpha$ and $\delta$ phases of $\mathrm{Bi}_{2} \mathrm{O}_{3}$ : A combined ab initio and x-ray spectroscopy study, Phys. Rev. B 73, 2006, 235104.

[43] ICDD PDF Card 027-0049

[44] L. Leontie M. Caraman, M. Delibas, G.I. Rusu, Optical properties of bismuth trioxide thin films, Materials Research Bulletin 36, 2001. 1629. 
[45] ICDD PDF Card 77-5341

[46] ICDD PDF Card 27-0052 


\section{Highlights}

-Influence of deposition parameters on as grown films' properties was investigated

- $\mathrm{By}$ tuning the $\mathrm{O} / \mathrm{Bi}$ atomic ratio, $\mathrm{Bi}, \delta-\mathrm{Bi}_{2} \mathrm{O}_{3}, \alpha-\mathrm{Bi}_{2} \mathrm{O}_{3}$ or mixtures can be deposited

-There is a narrow process window where high oriented pure $\delta-\mathrm{Bi}_{2} \mathrm{O}_{3}$ films are obtained

-Delta-alpha phase transformation can occur during TEM sample preparation 